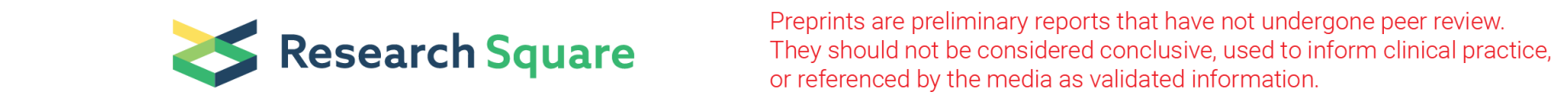

\title{
Rethinking of The Zone of Proximal Development: The Role of Parental Engagement in Children's Language Learning Skills
}

Elham Akbari ( $\square$ eakbari@modares.ac.ir)

Tarbiat Modares University

\section{Research Article}

Keywords: zone of proximal development(ZDP), parental involvement, language skill, social networks, involvement

Posted Date: January 7th, 2022

DOI: https://doi.org/10.21203/rs.3.rs-1208825/v1

License: (9) (1) This work is licensed under a Creative Commons Attribution 4.0 International License. Read Full License 


\section{Abstract}

The present research investigated the efficacy of parent engagement in children's learning and achievement in the English language. It is emphasized that adult guidance in foreign language learning cannot necessarily play an influential role in children's zone of proximal development (ZPD). It seems that parents or adults should enjoy relative linguistic skills, while in Vygotsky's theory, there is ambiguity over some concepts such as adult guidance characteristics.

The statistical society consisted of sixty Iranian children ranging from 9 to 10, divided randomly into three groups of experimental 1 , experimental 2 , and control. Children received face-to-face education while Telegram was used for their parents. The research results showed significantly more learning, skill training, parent involvement, and shared activities between children and parents in the experimental 1 and experimental 2 groups compared to the control group. Moreover, a positive correlation is found between parent involvement and children's achievement in all three groups. The results also showed that parents' involvement and teaching involvement, and language skills had the most influence on parents' involvement. Furthermore, teaching engagement to parents had the most significant influence on children's activities. In addition, children's activities and language skill training had the most influence on their learning.

\section{Introduction}

Iranian families are highly interested in learning the English language by their children, while most do not even know a dozen English words.

Besides, various institutes try to teach the English language to children for the considerable money they receive. However, they are not that successful in their job. Such lack of success can be due to different reasons, including parents' unfamiliarity with the English language. Children face many words only in the classroom, and there is no environment available outside the classroom for them to use or listen to those words! They can use the knowledge or words they have learned neither outside nor inside the house! The language spoken in the environment is entirely their mother tongue. There is no opportunity for the child to use and consolidate his/her learnings even though one of the essential elements in learning a foreign language is presence and attendance in an environment to use the target language and interact and communicate through it (Sargsyan \& Kurghinyan, 2016).

We found out that the home environment and the family are the easiest to manipulate and make positive changes. In other words, parents' engagement in their children's language learning can be changed and increased in different aspects. It should be noted that over 70 percent of a child's waking time is spent at home and outside school (Michigan Department of Education 2001).

Rieber \& Robinson (2004) argues that humans are encompassed by their family members and change and develop under the influence of the culture governing the family and environment they live in. As Kemal Tekin (2008), Ph.D. states, a child's early learnings occur through interaction with family. Consequent interactions can also lead to learning and change. Therefore, if children can receive help from parents in learning and exercising, they will have increased motivation to learn besides the fact that the environment will be more suitable for learning due to parents' engagement. Ma Xiaoyi (2017) states that parents' effective engagement can be constructive when a child is trying to learn a foreign language.

Different studies (Erdener and Knoeppel,2018; Henderson \& Mapp, 2002; Hoover-Dempsey\& Jones, 1997; Mac Naughton, 2005; Shim, 2013; Waterman, 2009; Xiao and et al.,2011) support the effectiveness of parents' 
engagement and their valuable and critical role in the learning process. Although Forey et al. (2016) argued that there was not much information on parent involvement and the way they support foreign language learning in children. In addition, there are more specialized studies on the influence of parents' engagement in learning English as a foreign language, each dealing with one or several formats through which parents participate and influence learning. For example, Ma Xiaoyi2017 indicated in his M.A. thesis that parents' engagement in interaction with school can help improve the English language in 6-12-year-old students.

Nutbrown, Hannon, and Morgan (2005) argued that parents had four critical roles in developing a child's language learning: O, R, I, M standing for opportunities, recognition, interaction, and model, respectively.

Table 1.Four significant ways parents can help literacy development in children (Nutbrown, Hannon, \& Morgan, 2005, p.50)

\begin{tabular}{|ll|}
\hline O & Opportunities \\
\hline R & Recognition \\
\hline I & Interaction \\
\hline M & Mode \\
\hline
\end{tabular}

Goodall (2013) introduces a model for effective parental engagement based on six elements that include authoritative parenting (which underpins the other five elements) and the need to begin engagement early, to take an active (rather than passive or reactive) interest in the child's learning, to continue this interest throughout the child's life, to have high educational aspirations and to stay engaged.

Moreover, parental engagement is defined in different ways. As Ireland (2014) states, parental engagement refers to the amount of engagement a parent has regarding schooling and her child's life. Redding (1992) states that parental engagement is related to parental engagement in learning. That engagement is neither restricted only within the home environment nor is limited to a specific learning exercise. Habit formation and attitude development, which create opportunities for children for academic learning, are the essential components of that engagement. Epstein (2010) suggested six types of interactions that can help family and school influence children's learning. Fishel \& Ramirez (2005) argue that parental engagement is generally referred to as parents' engagement in their children's education to promote their academic and social success.

\subsection{Theoretical framework:}

It can be claimed that Vygotsky's learning theory has turned into the most critical and popular theoretical framework for studies dealing with parents' interaction with children in the learning process (Kucirkova, Sheehy \& Messer,2015).

In his famous theory, Vygotsky emphasizes a child's interaction and communication with an adult or capable peer and believes that through this interaction, guidance, and support, a child faces a problem-solving situation and increases the available knowledge level. He also believes that social and cultural factors influence children's development and learning and promote their capabilities. In Vygotsky's perspective, every child has a zone of proximal development. In other words, there is an area called Zone of Proximal Development (ZPD) between what a 
child learns and what he/she can learn with the help and support of an adult or guide (Vygotsky, 1978). Therefore, early learnings occur in this area. The concept of ZPD emphasizes the social aspects of learning. It shows that an adult or competent individual in the learning process can effectively help the learner ( Prior \& Gerard, 2007). Such interaction can even lead to advanced thinking skills in the child (Lawton,2017).In fact, in Vygotsky's point of view, interaction is based on cooperation and the basis of learning and development. Ailincai, Gabillon, Vernaudon, Paia\& Alì. (2016) argue that learning occurs better and more through interaction and cooperation in the zone of proximal development.

\section{Statement of the problem}

Both Vygotsky's theory and the discourse and definitions presented above evidently show the importance of the role of parental engagement in their children's learning achievement, and it is emphasized that parental engagement can be represented in different ways and comprises different factors. However, Iranian parents cannot have an appropriate engagement in learning the English language of their children due to unfamiliarity with the English language. They play the role of a driver to transfer their children to language institutes, and at best, they encourage their children to learn a language.

Kavanagh and Hickey (2013) argued that one of the most critical obstacles to parental engagement in foreign language learning is parents' unfamiliarity with the target language. They ascertain that when parents do not have enough skills in the related language, they will not have enough self-confidence to help their children. In contrast, Brannon and Dauksas (2012) emphasized that parents' language skills considerably influence their children's success since by using them, parents can help their children through different activities.

Yusup \& Mansora (2016) argued that educated parents who learn the English language are more motivated to help their children and provide more substantial support for their children's learning activities. However, unfortunately, a little search in resources reveals that one can hardly find studies on the influence of parents' education on the degree of their engagement despite the importance of parental engagement in the education and learning of their children.

Therefore, the present research tried to teach the English language to parents via social networks to make positive changes in their engagement in the learning process. As stated in Vygotsky's theory, an adult guiding the child in the learning process is essential. It is noteworthy that today social networks are widely used by adults. Moreover, the interaction being one of the elements of learning a foreign language is rarely accessible in Iran's environment, and families are not familiar with the English language. So the interaction between children and parents in the language learning process through the English language can influence the degree of learning and help them provide the zone of proximal development based on interactions and social relationships between parents and capable peers and children.

\section{Methods}

A quasi-experimental procedure with a pretest-posttest design was implemented to identify the relationships of the intervention, parents' training for participation, by comparing treated units (kids) to control units. The purpose was to recognize the relationships among language teaching, parents' training for participation, kids' activities, parents' involvement, and learning level in the three groups. Thus, a comparison was made between two groups of kids and a control group of kids that their parents received no training. The aim was to evaluate performances between the groups.

\section{Participants}


The Statistical Population comprises 60 Iranian children between 9 and 10 and their parents who neither are familiar with the English language at all (they know just several English words). The 60 children were divided into two groups of experimental 1 and experimental 2 and the control group.

\section{The Experimental Group}

The experimental group 1 consisted of 20 children learning English through face-to-face classroom. At the same time, their parents were taught through Telegram (the most favorite social network in Iran) with the use of educational videos and short texts. The parents of this group participated in a 6_hour workshop on how to involve in the program. The experimental group 2 consisted of 20 children learning English through face-to-face classrooms. Their parents only participated in the six-hour workshop mentioned above and were not taught the English language at all.

\section{The Control Group}

In the control group, the children were just taught the English language and their parents neither learned English nor participated in the workshop on how to involve.

\section{The intervention}

The intervention in the experimental and the control group as mentioned earlier, both experimental groups participated separately in a workshop before the program. They were taught the methods and ways of involvement and were encouraged to participate more actively in their children's learning process. They were told that they can help their children in story reading, doing the exercises, memorizing words, reading English poems and watching animated cartoons.

\section{The instruments}

A pretest and a posttest were conducted. An English Language Course was used to assess kids' learning performance. On a scale of 0.00 to 0.99 , reliability coefficients generally fall between 0.75 and 0.86 (Educational Testing Service, 2005).

\section{Questionnaire}

A set of questionnaires, called "PI-SHBScienceLAS" adopted from Karaçöp et al. (2016) were answered by participants before and after the course.

Questionnaire items

Active Involvement of Parents: This questionnaire consisted of seven items and measured parents' involvement level in the learning process of kids. The related items are: "I allocate time to make studies with my child improving his/her English Language skills", "I am telling my child that I like to learn new things about English language", "I have enough knowledge to help my child with his/her assignment of English language", "I establish clear rules for my child to do his/her assignment at home”, and "I enjoy helping my child with his/her assignment of English language lesson”, "While helping my child with his/her assignment of English language lesson, I can make explanations by giving examples apart from the ones given in the book", and "By helping my child with his/her assignment of English language lesson I think that I make a difference in his/her school performance" ". A reliability test on the 5 -item (1 = totally disagree, 5 = totally agree) scale indicated an acceptable internal consistency $(a=.75)$. 
Engagement: Respondents were divided in two groups. A group has received training and another one, has not received training.

Parents and student's joint activities: This scale contained five items. Respondents were asked to determine the activities including Homework, Word, Reading the story, Poem, and Cartoon in which have done along with their kids.

Level of students' learning: The scale includes an item on a four-degree spectrum, from 1 (weak) to 4 (excellent).

Language teaching: The experimental groups were received language teaching to participate the in the learning process of their kids.

\section{Analytical procedure}

The statistical procedures employed to answer the research questions in chronological order, are:

1. Multivariate Analysis of Variance (MANOVA)

2. Pearson correlation analysis

3. Partial Least Square (PLS)

4. Multiple regression analysis

The data was also analyzed by the Statistical Package for the Social Sciences, version 22.0 and XLSTAT Premium version 19.

\section{First question: How will parents' training affect their children's participation, actions, and learning levels?}

Table number 2 shows the mean and standard deviation for some variables, including students' learning, parents' participation, and joint activities of parents and students. Descriptive statistics show that the mean scores related to the students' level of skills and learning (3.70) and the parents' participation level (3.49) were higher in the first experimental group than the second group and the control group. In addition, in the first experimental group, the mean of activities including assignments (14.55), writings (52.75), reading stories (19.99), poetry (4.25), and cartoon comprehension (11.55) was more than the second experimental group and also the control group. Furthermore, the second experiment group had higher means in the three variables above than the control group.

Table 2. Descriptive Statistics 


\begin{tabular}{|c|c|c|c|c|c|}
\hline Variable & Dimension & Group & Mean & $\begin{array}{l}\text { Std. } \\
\text { Deviation }\end{array}$ & $\mathrm{N}$ \\
\hline \multirow[t]{3}{*}{ Learning level of kids } & \multirow[t]{3}{*}{-} & $\begin{array}{l}\text { Experimental group } \\
1\end{array}$ & 3.70 & 0.66 & 20 \\
\hline & & $\frac{\text { Experimental group }}{2}$ & 2.70 & 0.47 & 20 \\
\hline & & Control group & 2.10 & 0.45 & 20 \\
\hline \multirow[t]{3}{*}{ Parents participation } & \multirow[t]{3}{*}{-} & Experimental group & 3.49 & 0.25 & 20 \\
\hline & & $\begin{array}{l}\text { Experimental group } \\
2\end{array}$ & 2.50 & 0.20 & 20 \\
\hline & & Control group & 1.24 & 0.23 & 20 \\
\hline \multirow[t]{15}{*}{$\begin{array}{l}\text { Joint activities of parents and } \\
\text { students }\end{array}$} & \multirow[t]{3}{*}{ Homework } & $\begin{array}{l}\text { Experimental group } \\
1\end{array}$ & 14.55 & 0.60 & 20 \\
\hline & & $\begin{array}{l}\text { Experimental group } \\
2\end{array}$ & 13.60 & 1.19 & 20 \\
\hline & & Control group & 11.20 & 1.47 & 20 \\
\hline & \multirow[t]{3}{*}{ Word } & $\begin{array}{l}\text { Experimental group } \\
1\end{array}$ & 52.75 & 2.15 & 20 \\
\hline & & $\begin{array}{l}\text { Experimental group } \\
2\end{array}$ & 43.85 & 3.34 & 20 \\
\hline & & Control group & 21.00 & 5.74 & 20 \\
\hline & \multirow[t]{3}{*}{$\begin{array}{l}\text { Reading the } \\
\text { story }\end{array}$} & $\begin{array}{l}\text { Experimental group } \\
1\end{array}$ & 19.90 & 1.29 & 20 \\
\hline & & $\begin{array}{l}\text { Experimental group } \\
2\end{array}$ & 18.60 & 1.64 & 20 \\
\hline & & Control group & 8.90 & 1.77 & 20 \\
\hline & \multirow[t]{3}{*}{ Poem } & $\begin{array}{l}\text { Experimental group } \\
1\end{array}$ & 4.25 & 0.55 & 20 \\
\hline & & $\begin{array}{l}\text { Experimental group } \\
2\end{array}$ & 2.75 & 0.44 & 20 \\
\hline & & Control group & 0.90 & 0.64 & 20 \\
\hline & \multirow[t]{3}{*}{ Cartoon } & $\begin{array}{l}\text { Experimental group } \\
1\end{array}$ & 11.55 & 1.39 & 20 \\
\hline & & $\begin{array}{l}\text { Experimental group } \\
2\end{array}$ & 8.60 & 2.35 & 20 \\
\hline & & Control group & 2.65 & 0.49 & 20 \\
\hline
\end{tabular}

Multivariate Analysis of Variance (MANOVA) was used in order to review training of parents concerning their participation, the amount it had affected their participation, actions, and learning level of students, and also by regarding specific training for parents (participatory and verbal) that is in complete contrast to the first and second experimental group and control group. 
In this test, related variables should have a meaningful relationship. For example, the dependent variables of parents' participation, mutual actions (parents and students), and learning level of students have theoretically close relationships with each other by means that it is expected to increase parents' participation, actions, and learning level students increase. Before applying the MANOVA test, the test assumptions were examined by Box ${ }^{1}$, Levene ${ }^{2}$, Pillai's Trace $^{3}$, Wilks' Lambda ${ }^{4}$, Hotelling's Trace ${ }^{5}$, and Roy's Largest Root. The box test was used for three variables to examine the equality of the variance-covariance matrix. The results of the box test are shown in the table below. Table 2 shows the level of significance $(p=0.05)$, which indicates that the equality condition of the variance-covariance matrix is well observed $(P<0.05, F=2.069)$.

Table 3. Box's Test of Equality of Covariance Matrices

\begin{tabular}{|ll|}
\hline Box's M & 141.067 \\
\hline F & 2.069 \\
\hline df1 & 56 \\
\hline df2 & 9280.317 \\
\hline Sig. & .000 \\
\hline
\end{tabular}

Levene test was used to review equality of variances of learning level, skill learning of students, parents' participation, and joint actions of parents and students. The Levene test results have been represented below table. This table shows that the variances of these three variables are not equal in the three groups (1 and 2) and the control group. However, they are significantly distinctive $(P \leq 0.05)$, which indicates the reliability of the following represented results.

Table 4. Levene's Test of Equality of Error Variances

\begin{tabular}{|lllll|}
\hline & $F$ & $d f 1$ & $d f 2$ & Sig. \\
\hline Learning level & 2.019 & 2 & 57 & .042 \\
\hline Parents participation & 3.831 & 2 & 57 & .031 \\
\hline Homework & 14.084 & 2 & 57 & .000 \\
Word & 2.731 & 2 & 57 & .036 \\
\hline Reading the story & 5.721 & 2 & 57 & .018 \\
\hline Poem & 2.335 & 2 & 57 & .027 \\
\hline Cartoon & 7.591 & 2 & 57 & .001 \\
\hline
\end{tabular}

In the below table, the results of the Wilks' Lambda test are represented. The Wilks Lambda test statistics fluctuate between zero and one. Moreover, when approaching zero, it shows the more significant difference in the average of quantitative variables that, as approaching one, means no difference in means between groups.

Results showed that among the three experimented groups, there was a meaningful distinction at least among one of the below variables: learning level, skill learning of students, parents' participation, and joint actions of parents and students $(130 / 87 \mathrm{~F}=05 / 0 \mathrm{P} \leq)$.

Table 5. Multivariate Tests

Page 8/28 


\begin{tabular}{|lllllll|}
\hline Effect & & Value & F & Hypothesis df & Error df & Sig. \\
\hline Intercept & Wilks' Lambda & 0.001 & $6470.744^{\mathrm{b}}$ & 7 & 51 & 0.000 \\
\cline { 3 - 7 } & & 0.006 & $87.130^{\mathrm{b}}$ & 14 & 102 & 0.000 \\
\hline
\end{tabular}

Effects of each one of the quantitative variables (levels of learning and skills learning of students, parental participation, and joint activities of parents and children) are studied in the form of three independent test groups (1 and 2) and control groups as well as the interactive effects of these three variables on each other according to the results of Box, Levene, Wilks' Lambda tests. The results are shown in the following table. Based on this table, there are meaningful distinction between the three groups ( 1 and 2 ) and control groups in the level of learning and skills learning level of students (FF45 = 975 and P0.05), parental participation rate $(\mathrm{F}=483.5115,0 \mathrm{P} \leq)$, classroom activities and homework ( $F=339.45$ and P0.05), word maintenance activity $(330 / 114 \mathrm{~F}=$ and $05 / 0 P \leq)$, reading story activity $(F=289243 / 0$ and $P 0.05 / 24)$, Reading poetry ( $F F=185.555, P \leq 0.05)$ and cartoon perception activity $(160 \mathrm{~F}=149$ and $\mathrm{P} \leq 0.05)$.

Therefore, there is a significant difference between the responses of the test and control groups for the three variables presented in the following table. In other words, the level of learning and student skills, parental participation, and joint activities of parents and children in the experimental groups ( 1 and 2 ) and the control group are not similar. Furthermore, the variance of training for participation is $\% 61 / 7$. The variance of students' level of learning and skills is 61/7 percent, parental participation 94.4 percent, homework, and activities 61.4 percent. The vocabulary conservation and learning activity variance is 92.1 percent, poetry 91 percent, and cartoon perception activities 84/9.

\section{Table 6. Tests of Between-Subjects Effects}

\begin{tabular}{|llllllll|}
\hline $\begin{array}{l}\text { Dependent } \\
\text { Variable }\end{array}$ & $\begin{array}{l}\mathrm{R} \\
\text { Squared }\end{array}$ & $\begin{array}{l}\text { Adjusted R } \\
\text { Squared }\end{array}$ & $\begin{array}{l}\text { Sum of } \\
\text { Squares }\end{array}$ & df & $\begin{array}{l}\text { Mean } \\
\text { Square }\end{array}$ & F & Sig. \\
\hline Learning level & .617 & .604 & 26.133 & 2 & 13.067 & 45.975 & .000 \\
\hline $\begin{array}{l}\text { Parent } \\
\text { participation }\end{array}$ & .944 & .942 & 50.550 & 2 & 25.275 & 483.511 & .000 \\
\hline Homework & .614 & .600 & 119.233 & 2 & 59.617 & 45.339 & .000 \\
\hline Word & .921 & .918 & 10729.300 & 2 & 5364.650 & 330.114 & .000 \\
\hline Reading the story & .910 & .907 & 1445.200 & 2 & 722.600 & 289.243 & .000 \\
\hline Poem & .867 & .862 & 112.633 & 2 & 56.317 & 185.552 & .000 \\
\hline Cartoon & .849 & .844 & 822.100 & 2 & 411.050 & 160.149 & .000 \\
\hline
\end{tabular}

Now post hoc test is used for understanding if there are differences among these groups. In this study, an LSD followup test was used to measure the issue mentioned above (see below table), which is neutral compared to the sample size of the various groups and has the prerequisite for equality of variances. If the difference between the two groups is more than the constant value of LSD, then there is a significant difference between the two groups.

It is important to note two points in performing this test: first, this test should be used when the value of the $F$ is significant in the analysis table of the variance; the second number of groups should not be so many. Therefore, both of these preconditions are true in this research. Second, according to the results of the post hoc test between the experimental group 1 and 2, the experimental group No. 1 and the control group, and the experimental group 2 and the 
control group, variables' mean of the level of learning and student skills, parental participation, and joint activities of parents and children have significant differences (P0.05). Also, for the lower and upper bound mark, the mean of these three variables was higher for experimental group 1 than control group 2 and control group. In addition, both groups 1 and 2 had a greater mean than the control group.

Table 7. Multiple Comparisons (LSD posthoc test) 


\begin{tabular}{|c|c|c|c|c|c|c|c|}
\hline \multirow[t]{2}{*}{$\begin{array}{l}\text { Dependent } \\
\text { Variable }\end{array}$} & \multirow[t]{2}{*}{ (I) group } & \multirow[t]{2}{*}{ (J) group } & \multirow[t]{2}{*}{$\begin{array}{l}\text { Mean } \\
\text { Difference }(I-J)\end{array}$} & \multirow[t]{2}{*}{$\begin{array}{l}\text { Std. } \\
\text { Error }\end{array}$} & \multirow[t]{2}{*}{ Sig. } & \multicolumn{2}{|c|}{$\begin{array}{l}95 \% \text { Confidence } \\
\text { Interval }\end{array}$} \\
\hline & & & & & & $\begin{array}{l}\text { Lower } \\
\text { Bound }\end{array}$ & $\begin{array}{l}\text { Upper } \\
\text { Bound }\end{array}$ \\
\hline \multirow[t]{6}{*}{ Learning level } & \multirow[t]{2}{*}{$\begin{array}{l}\text { Experimental } \\
\text { group } 1\end{array}$} & $\begin{array}{l}\text { Experimental } \\
\text { group } 2\end{array}$ & $1.00^{*}$ & 0.17 & .000 & 0.66 & 1.34 \\
\hline & & Control group & $1.60^{*}$ & 0.17 & .000 & 1.26 & 1.94 \\
\hline & \multirow[t]{2}{*}{$\begin{array}{l}\text { Experimental } \\
\text { group } 2\end{array}$} & $\begin{array}{l}\text { Experimental } \\
\text { group } 1\end{array}$ & $-1.00^{*}$ & 0.17 & .000 & -1.33 & -0.66 \\
\hline & & Control group & $.60^{*}$ & 0.17 & .001 & 0.26 & 0.94 \\
\hline & \multirow[t]{2}{*}{ Control group } & $\begin{array}{l}\text { Experimental } \\
\text { group } 1\end{array}$ & $-1.60^{*}$ & 0.17 & .000 & -1.94 & -1.26 \\
\hline & & $\begin{array}{l}\text { experimental } \\
\text { group } 2\end{array}$ & $-.60^{*}$ & 0.17 & .001 & -0.94 & -0.26 \\
\hline \multirow[t]{6}{*}{$\begin{array}{l}\text { Parent } \\
\text { participation }\end{array}$} & \multirow[t]{2}{*}{$\begin{array}{l}\text { Experimental } \\
\text { group } 1\end{array}$} & $\begin{array}{l}\text { experimental } \\
\text { group } 2\end{array}$ & $.98^{*}$ & 0.07 & .000 & 0.84 & 1.13 \\
\hline & & Control group & $2.24^{\star}$ & 0.07 & .000 & 2.10 & 2.39 \\
\hline & \multirow[t]{2}{*}{$\begin{array}{l}\text { Experimental } \\
\text { group } 2\end{array}$} & $\begin{array}{l}\text { Experimental } \\
\text { group } 1\end{array}$ & $-.98^{*}$ & 0.07 & .000 & -1.13 & -0.84 \\
\hline & & Control group & $1.25^{\star}$ & 0.07 & .000 & 1.11 & 1.40 \\
\hline & \multirow[t]{2}{*}{ Control group } & $\begin{array}{l}\text { Experimental } \\
\text { group } 1\end{array}$ & $-2.24^{\star}$ & 0.07 & .000 & -2.39 & -2.10 \\
\hline & & $\begin{array}{l}\text { experimental } \\
\text { group } 2\end{array}$ & $-1.25^{*}$ & 0.07 & .000 & -1.40 & -1.11 \\
\hline \multirow[t]{6}{*}{ Homework } & \multirow[t]{2}{*}{$\begin{array}{l}\text { Experimental } \\
\text { group } 1\end{array}$} & $\begin{array}{l}\text { experimental } \\
\text { group } 2\end{array}$ & $.95^{\star}$ & 0.36 & .011 & 0.22 & 1.68 \\
\hline & & Control group & $3.35^{\star}$ & 0.36 & .000 & 2.62 & 4.08 \\
\hline & \multirow[t]{2}{*}{$\begin{array}{l}\text { Experimental } \\
\text { group } 2\end{array}$} & $\begin{array}{l}\text { Experimental } \\
\text { group } 1\end{array}$ & $-.9500^{*}$ & 0.36 & .011 & -1.68 & -0.22 \\
\hline & & control group & $2.40^{*}$ & 0.36 & .000 & 1.67 & 3.13 \\
\hline & \multirow[t]{2}{*}{ Control group } & $\begin{array}{l}\text { Experimental } \\
\text { group } 1\end{array}$ & $-3.35^{*}$ & 0.36 & .000 & -4.08 & -2.62 \\
\hline & & $\begin{array}{l}\text { Experimental } \\
\text { group } 2\end{array}$ & $-2.40^{*}$ & 0.36 & .000 & -3.13 & -1.67 \\
\hline \multirow[t]{4}{*}{ Word } & \multirow[t]{2}{*}{$\begin{array}{l}\text { Experimental } \\
\text { group } 1\end{array}$} & $\begin{array}{l}\text { Experimental } \\
\text { group } 2\end{array}$ & $8.90^{*}$ & 1.27 & .000 & 6.35 & 11.45 \\
\hline & & control group & $31.75^{*}$ & 1.27 & .000 & 29.20 & 34.30 \\
\hline & \multirow[t]{2}{*}{$\begin{array}{l}\text { Experimental } \\
\text { group } 2\end{array}$} & $\begin{array}{l}\text { Experimental } \\
\text { group } 1\end{array}$ & $-8.90^{*}$ & 1.27 & .000 & -11.45 & -6.35 \\
\hline & & control group & $22.85^{*}$ & 1.27 & .000 & 20.30 & 25.40 \\
\hline
\end{tabular}




\begin{tabular}{|c|c|c|c|c|c|c|c|}
\hline & Control group & $\begin{array}{l}\text { Experimental } \\
\text { group } 1\end{array}$ & $-31.75^{\star}$ & 1.27 & .000 & -34.30 & -29.20 \\
\hline & & $\begin{array}{l}\text { Experimental } \\
\text { group } 2\end{array}$ & $-22.85^{*}$ & 1.27 & .000 & -25.40 & -20.30 \\
\hline \multirow[t]{6}{*}{$\begin{array}{l}\text { Reading the } \\
\text { story }\end{array}$} & \multirow[t]{2}{*}{$\begin{array}{l}\text { Experimental } \\
\text { group } 1\end{array}$} & $\begin{array}{l}\text { Experimental } \\
\text { group } 2\end{array}$ & $1.30^{*}$ & 0.50 & .012 & 0.30 & 2.30 \\
\hline & & Control group & $11.00^{\star}$ & 0.50 & .000 & 10.00 & 12.00 \\
\hline & \multirow[t]{2}{*}{$\begin{array}{l}\text { Experimental } \\
\text { group } 2\end{array}$} & $\begin{array}{l}\text { Experimental } \\
\text { group } 1\end{array}$ & $-1.30^{*}$ & 0.50 & .012 & -2.30 & -0.30 \\
\hline & & Control group & $9.70^{*}$ & 0.50 & .000 & 8.70 & 10.70 \\
\hline & \multirow[t]{2}{*}{ Control group } & $\begin{array}{l}\text { Experimental } \\
\text { group } 1\end{array}$ & $-11.00^{*}$ & 0.50 & .000 & -12.00 & -10.00 \\
\hline & & $\begin{array}{l}\text { Experimental } \\
\text { group } 2\end{array}$ & $-9.70^{*}$ & 0.50 & .000 & -10.70 & -8.70 \\
\hline \multirow[t]{6}{*}{ Poem } & \multirow[t]{2}{*}{$\begin{array}{l}\text { Experimental } \\
\text { group } 1\end{array}$} & $\begin{array}{l}\text { Experimental } \\
\text { group } 2\end{array}$ & $1.50^{\star}$ & 0.17 & .000 & 1.15 & 1.85 \\
\hline & & Control group & $3.35^{*}$ & 0.17 & .000 & 3.00 & 3.70 \\
\hline & \multirow[t]{2}{*}{$\begin{array}{l}\text { Experimental } \\
\text { group } 2\end{array}$} & $\begin{array}{l}\text { Experimental } \\
\text { group } 1\end{array}$ & $-1.50^{*}$ & 0.17 & .000 & -1.85 & -1.15 \\
\hline & & Control group & $1.85^{\star}$ & 0.17 & .000 & 1.50 & 2.20 \\
\hline & \multirow[t]{2}{*}{ Control group } & $\begin{array}{l}\text { Experimental } \\
\text { group } 1\end{array}$ & $-3.35^{\star}$ & 0.17 & .000 & -3.70 & -3.00 \\
\hline & & $\begin{array}{l}\text { Experimental } \\
\text { group } 2\end{array}$ & $-1.85^{*}$ & 0.17 & .000 & -2.20 & -1.50 \\
\hline \multirow[t]{6}{*}{ Cartoon } & \multirow[t]{2}{*}{$\begin{array}{l}\text { Experimental } \\
\text { group } 1\end{array}$} & $\begin{array}{l}\text { Experimental } \\
\text { group } 2\end{array}$ & $2.95^{\star}$ & 0.51 & .000 & 1.94 & 3.96 \\
\hline & & Control group & $8.90^{\star}$ & 0.51 & .000 & 7.89 & 9.91 \\
\hline & \multirow[t]{2}{*}{$\begin{array}{l}\text { Experimental } \\
\text { group } 2\end{array}$} & $\begin{array}{l}\text { Experimental } \\
\text { group } 1\end{array}$ & $-2.95^{\star}$ & 0.51 & .000 & -3.96 & -1.94 \\
\hline & & Control group & $5.95^{*}$ & 0.51 & .000 & 4.94 & 6.96 \\
\hline & \multirow[t]{2}{*}{ Control group } & $\begin{array}{l}\text { Experimental } \\
\text { group } 1\end{array}$ & $-8.90^{*}$ & 0.51 & .000 & -9.91 & -7.89 \\
\hline & & $\begin{array}{l}\text { Experimental } \\
\text { group } 2\end{array}$ & $-5.95^{\star}$ & 0.51 & .000 & -6.96 & -4.94 \\
\hline
\end{tabular}

Second question. What kind of relationship is among parents' participation and level of their children's successes while learning a foreign language? 
Pearson correlation analysis was used to examine the relationship between the two variables of parental participation and the success rate of children in learning foreign languages by considering these two variables are quantitative. According to this table, the Correlation between the two variables of parents' participation and the success rate of children's learning for the first group was equal to $0 / 519$, for the second group was $0 / 391$. For the third group, it was 0/488, which is This rate is significant concerning the error level of 5 to $10 \%(P<0.05, P<0.1)$.

Therefore, it can be concluded that there is a moderate correlation between the two variables of parental participation and the success level of their children's learning in all three groups. Furthermore, it shows a direct and positive relationship meaning that if the parental participation level increases, the success level of students in learning foreign language skills will also improve.

Table 8. Pearsons' Correlations for the Groups

\begin{tabular}{|c|c|c|c|c|}
\hline & & $\begin{array}{l}\text { Learning level for } \\
\text { Group } 1\end{array}$ & $\begin{array}{l}\text { Learning level for } \\
\text { Group } 2\end{array}$ & $\begin{array}{l}\text { Learning level for } \\
\text { Group } 3\end{array}$ \\
\hline \multirow[t]{3}{*}{$\begin{array}{l}\text { Parent } \\
\text { participation }\end{array}$} & $\begin{array}{l}\text { Pearson } \\
\text { Correlation }\end{array}$ & $.519^{\star}$ & $.391 * *$ & $.488^{*}$ \\
\hline & Sig. (2-tailed) & .019 & .089 & .029 \\
\hline & $\mathrm{N}$ & 20 & 20 & 20 \\
\hline
\end{tabular}

Question 3: What is the relationship between language teaching and teaching engagement to parents and child activities in the three groups? (what is the relationship between research variables, and which variable has the most influence on learning degree in children?)

The Partial Least Square (PLS) approach as the second generation of structural equation modeling methods has created new insights for behavioral sciences researchers. Through presenting the latent variable modeling approach, it was concluded that by calculating the measurement error in scales that reduce the estimated relationship, more exact estimates could be obtained on interaction effects.

Two models are examined in PLS:

- outer models

- inner models

The outer model is similar to measuring the confirmatory factor analysis (CFA), and the inner model is similar to path analysis in structural equation modeling. After the outer model test, the inner model indicates the relationship between latent variables in the research. The model research hypotheses can be investigated through the inner model. The PLS analysis is performed in the XLSTAT environment.

\section{PLS model estimation}

The present research model is as follows:

$y t=f X 1, X 2, \ldots X n$

$\mathrm{Y}$, the dependent variables, and $\mathrm{X}$, the explanatory variables, are the factors that influence this variable. 
The dependent and explanatory variables in the present research are as follows:

explanatory variables:

$\mathrm{X} 1$ : language teaching

$\mathrm{X} 2$ : teaching engagement to parents

Dependent variables:

X3: degree of parent involvement

Y1: foreign language learning level

Y2: child activities

Using the PLS, the number of variables in the two components can be categorized.

The following table and graph show the quality of the estimated PLS model based on the number of components selected. When the $\mathrm{R}^{2}$ values for the dependent and independent variables of $\mathrm{X}$ and $\mathrm{Y}$ and the Q2 values approach 1, the PLS model is estimated more accurately.

Table 9. model efficacy indices with the two components

\begin{tabular}{lll} 
Index & Comp1 & Comp2 \\
\hline $\mathrm{Q}^{2}$ cum & 0.727 & 0.736 \\
\hline $\mathrm{R}^{2} \mathrm{Y}$ cum & 0.739 & 0.754 \\
\hline $\mathrm{R}^{2} \mathrm{X}$ cum & 0.749 & 1.000
\end{tabular}

A summary of the PLS model results in the first stage is presented in the following. This graph shows the Correlation between dependent variables and estimated independent variables. These variables are correlated less whenever the axes approach the center of the circle.

As observed, there is a strong positive correlation between the dependent variables (blue points) and the independent variables.

The following table shows the correlation matrix between explanatory variables of the model and each of the estimated components. As observed, there is a relatively strong correlation between the dependent variables of $\mathrm{X} 3$ (degree of parent involvement), Y1 (foreign language learning level), and Y2 (child activities) and the first component, namely $0.972,0.593$, and 0.960 , respectively.

Table 10. correlation matrix between model variables and each of the estimated components 


\begin{tabular}{lll} 
Variable & $\mathrm{t} 1$ & $\mathrm{t} 2$ \\
\hline $\mathrm{X} 1-0$ & -0.840 & 0.542 \\
\hline $\mathrm{X} 1-1$ & 0.840 & -0.542 \\
\hline $\mathrm{X} 2-0$ & -0.890 & -0.457 \\
\hline $\mathrm{X} 2-1$ & 0.890 & 0.457 \\
\hline $\mathrm{X} 3$ & 0.972 & 0.020 \\
\hline $\mathrm{Y} 1$ & 0.593 & -0.002 \\
\hline $\mathrm{Y} 2$ & 0.960 & 0.208
\end{tabular}

Based on the results in the following table, variables of X2 (teaching engagement to parents) and X1 (language teaching) have the highest impact on the estimated components, respectively.

In this table, the Upper and Lower bounds represent the acceptable domain of the calculated indices (confidence interval).

Table 11. variables most important in the first two components, respectively

\begin{tabular}{lllllllll} 
Variable & VIP & $\begin{array}{l}\text { Standard } \\
\text { deviation }\end{array}$ & $\begin{array}{l}\text { The lower } \\
\text { bound(95\%) }\end{array}$ & $\begin{array}{l}\text { Upper } \\
\text { bound(95\%) }\end{array}$ & VIP & $\begin{array}{l}\text { Standard } \\
\text { deviation }\end{array}$ & $\begin{array}{l}\text { The lower } \\
\text { bound(95\%) }\end{array}$ & $\begin{array}{l}\text { Upper } \\
\text { bound(95\%) }\end{array}$ \\
\hline X2-0 & 1.082 & 0.027 & 1.029 & 1.134 & 1.079 & 0.045 & 0.991 & 1.166 \\
\hline X2-1 & 1.082 & 0.027 & 1.029 & 1.134 & 1.079 & 0.045 & 0.991 & 1.166 \\
\hline X1-0 & 0.911 & 0.032 & 0.849 & 0.973 & 0.915 & 0.053 & 0.810 & 1.019 \\
\hline X1-1 & 0.911 & 0.032 & 0.849 & 0.973 & 0.915 & 0.053 & 0.810 & 1.019
\end{tabular}

Given the results delineated in the following table, it can be specified that all independent variables under study (language teaching and teaching engagement to parents) have a significant influence on the dependent variables.

Table 12. estimated coefficients for independent variables of the model and their standard deviations

\begin{tabular}{lllll} 
Variable & Coefficient & Std. deviation & The lower bound (95\%) & Upper bound (95\%) \\
\hline X1-0 & -0.146 & 0.015 & -0.177 & -0.116 \\
\hline X1-1 & 0.146 & 0.015 & 0.116 & 0.177 \\
\hline X2-0 & -0.401 & 0.014 & -0.428 & -0.375 \\
\hline X2-1 & 0.401 & 0.014 & 0.375 & 0.428
\end{tabular}

\section{Regression model estimation}

After recognizing essential variables influencing the degree of parent involvement, foreign language learning level, and child activities, regression models are specified to determine the influence of independent variables on the dependent variable. To do the analyses related to the linear regressions, SAS was utilized. Since three different groups (experimental1, experimental2, and control) were investigated in the present study, the influence of the independent 
variables on the dependent variables was calculated within several separate regression models while considering variables available in each experiment for groups 1 and 2 . A summary of the results is presented in the following table. As the regression analysis shows, there is a significant relationship between all variables in the conceptual model of the research $(P<0.001)$.

Table 13. Results of regression analysis with different independent and dependent variables 


\begin{tabular}{|c|c|c|}
\hline$X 3=1.872+1.614\left(0.81^{\star \star}\right) \times 1$ & 0.57 & 0.65 \\
\hline$X 3=1.243+1.750\left(0.87^{\star \star}\right) \times 2$ & 0.76 & 0.47 \\
\hline$X 3=1.243+0.985\left(0.49^{\star \star}\right) \times 1+1.258\left(0.63^{\star \star}\right) \times 2$ & 0.23 & 0.94 \\
\hline$Y 2=66.025+36.975\left(0.69^{* \star}\right) \times 1$ & 18.38 & 0.48 \\
\hline$Y 2=44.650+50.550\left(0.95^{\star \star}\right) \times 2$ & 8.04 & 0.90 \\
\hline$Y 2=19.060+24.608\left(0.93^{\star \star}\right) \times 3$ & 9.67 & 0.86 \\
\hline $\mathrm{Y} 2=44.650+15.600\left(0.29^{\star \star}\right) \mathrm{X} 1+42.750\left(0.80^{\star \star}\right) \mathrm{X} 2$ & 4.80 & 0.97 \\
\hline$Y 2=48.903-1.631\left(0.06^{n s}\right) X 1+9.362\left(0.69^{* \star}\right) X 3$ & 9.95 & 0.42 \\
\hline$Y 2=31.213+31.622\left(0.59^{\star \star}\right) X 2+10.814\left(0.41^{\star \star}\right) X 3$ & 6.31 & 0.94 \\
\hline$Y 2=51.678+21.168\left(0.40^{\star \star}\right) X 1+49.865\left(0.94^{\star \star}\right) X 2-5.656\left(0.21^{\star}\right) X 3$ & 4.67 & 0.97 \\
\hline $\mathrm{Y} 1=66.425+13.475\left(0.50^{* \star}\right) \mathrm{X} 1$ & 11.21 & 0.25 \\
\hline$Y 1=61.450+14.200\left(0.53^{* \star}\right) X 2$ & 11.00 & 0.28 \\
\hline$Y 1=49.940+8.706\left(0.65^{\star \star}\right) X 3$ & 9.87 & 0.42 \\
\hline $\mathrm{Y} 1=47.756+0.296\left(0.58^{\star \star}\right) Y 2$ & 10.51 & 0.34 \\
\hline$Y 1=61.450+8.500\left(0.31^{\star}\right) X 1+9.950\left(0.37^{\star \star}\right) X 2$ & 10.51 & 0.35 \\
\hline $\mathrm{Y} 1=48.903-1.631\left(0.06^{\mathrm{ns}}\right) \mathrm{X} 1+9.362\left(0.69^{\star \star}\right) \mathrm{X} 3$ & 9.95 & 0.42 \\
\hline $\mathrm{Y} 1=51.136+4.912\left(0.18^{\mathrm{ns}}\right) \mathrm{X} 1+0.232\left(0.46^{\star \star}\right) \mathrm{Y} 2$ & 10.46 & 0.36 \\
\hline $\mathrm{Y} 1=48.253-4.390\left(0.16^{\mathrm{ns}}\right) \mathrm{X} 2+10.622\left(0.79^{\star \star}\right) \mathrm{X} 3$ & 9.91 & 0.42 \\
\hline $\mathrm{Y} 1=42.287-7.494\left(0.28^{\mathrm{ns}}\right) \mathrm{X} 2+0.429\left(0.85^{*}\right) \mathrm{Y} 2$ & 10.54 & 0.35 \\
\hline$Y 1=50.93-9.987\left(0.74^{\star \star}\right) X 3-0.052\left(0.10^{n s}\right) Y 2$ & 9.95 & 0.42 \\
\hline $\mathrm{Y} 1=40.168-8.363\left(0.31^{\mathrm{ns}}\right) \mathrm{X} 1-11.598\left(0.43^{\mathrm{ns}}\right) \mathrm{X} 2+17.128\left(1.27^{\star \star}\right) \mathrm{X} 3$ & 9.85 & 0.44 \\
\hline$Y 1=51.845+5.144\left(0.19^{n s}\right) X 1+0.754\left(0.03^{n s}\right) X 2+0.215\left(0.42^{n s}\right) Y 2$ & 10.55 & 0.36 \\
\hline$Y 1=46.113-6.558\left(0.24^{n s}\right) X 2+9.880\left(0.73^{\star \star}\right) X 3+0.069\left(0.14^{n s}\right) Y 2$ & 9.99 & 0.43 \\
\hline $\mathrm{Y} 1=49.842-2.148\left(0.08^{\mathrm{ns}}\right) \mathrm{X} 1+11.206\left(0.83^{\star}\right) \mathrm{X} 3-0.066\left(0.13^{\mathrm{ns}}\right) \mathrm{Y} 2$ & 10.02 & 0.42 \\
\hline$Y 1=16.045-18.244\left(0.68^{\star}\right) X 1-34.875\left(1.29^{\star}\right) X 2+19.769\left(1.47^{\star \star}\right) X 3+0.467\left(0.92^{n s}\right) Y 2$ & 9.69 & 0.47 \\
\hline
\end{tabular}

Notes: The numbers in parentheses are standardized regression coefficients; ${ }^{\text {ns }} P>0.05 ; * P \leq 0.05 ; * \star P \leq 0.01$ 
In order to recognize the most important variables influencing the learning level in students, standard regression coefficients related to the relationship between each pair of the research variables are presented in the following graph. Results showed that from among variables explaining the degree of parent involvement, the variable of teaching engagement to parents was the most effective $(P<0.001 ; \beta=0.87)$, followed by the variable of language teaching $(P<0.001 ; \beta=0.81)$. Moreover, the results showed that from among variables predicting child activities, teaching engagement to parents (engagement $<0.001 ; \beta=0.95$ ), parent involvement (parent involvement $<0.001$; $\beta=0.93$ ), language teaching (Language teaching $<0.001 ; \beta=0.69$ ) had the most influence respectively.

It was interesting that the direct influence of language teaching $(\beta=0.69)$ on child activities was less than its indirect influence of parent involvement degree (parent involvement) $(0.81 \times 0.93=0.75)$. Compared to the direct influence, language teaching through the variable of parent involvement degree had more influence on child activities. Finally, parent involvement (parent involvement $<0.001 ; \beta=0.65$ ), child activities (activities $<0.001 ; \beta=0.58$ ), and language teaching (language teaching $<0.001 ; \beta=0.50$ ) had the most influence on the dependent variable of foreign language learning level respectively.

\section{Question number 4. What kind of relationship is there among students' and parents' actions with the level of foreign language learning in three experimental groups?}

Pearson correlation test was used to answer this question. According to the table below, the correlation coefficient ${ }^{\circledR}$ between the two variables of parental participation and the success rate of students learning for the first group was 0.384 , which is significant at a $10 \%$ error level (P-value $<0.1)$. Therefore, it can be concluded that there is a weak correlation between students' and their parents' activities and learning in the first group. Furthermore, this is a direct and positive relationship, meaning that the higher the parents' and students' activities, the greater the students' success in learning foreign language skills. However, this relationship was not significant for the second experimental and control groups (P-value> 0.5).

Table 14. Pearsons' Correlations for the Groups

\begin{tabular}{|c|c|c|c|c|}
\hline & & $\begin{array}{l}\text { Learning level for Group } \\
1\end{array}$ & $\begin{array}{l}\text { Learning level for Group } \\
2\end{array}$ & $\begin{array}{l}\text { Learning level for Group } \\
3\end{array}$ \\
\hline \multirow[t]{3}{*}{ Activities } & $\begin{array}{l}\text { Pearson } \\
\text { Correlation }\end{array}$ & 0.384 & 0.209 & -0.250 \\
\hline & Sig. (2-tailed) & 0.095 & 0.377 & 0.288 \\
\hline & $\mathrm{N}$ & 20 & 20 & 20 \\
\hline
\end{tabular}

For better representation of this figure, the MONOVA was recalculated by computing the mean of activities shown in this figure.

Table 15. Tests of Between-Subjects Effects 


\begin{tabular}{|c|c|c|c|c|c|c|}
\hline \multicolumn{7}{|c|}{ Tests of Between-Subjects Effects } \\
\hline Source & Dependent Variable & Type III Sum of Squares & Df & Mean Square & $\mathrm{F}$ & Sig. \\
\hline \multirow[t]{3}{*}{ Corrected Model } & Learning level & $26.133^{a}$ & 2 & 13.067 & 45.975 & .000 \\
\hline & Parent participation & $50.550^{b}$ & 2 & 25.275 & 483.511 & .000 \\
\hline & activities & $36504.300^{c}$ & 2 & 18252.150 & 790.947 & .000 \\
\hline \multirow[t]{3}{*}{ Intercept } & Learning level & 481.667 & 1 & 481.667 & 1694.753 & .000 \\
\hline & Parent participation & 348.348 & 1 & 348.348 & 6663.951 & .000 \\
\hline & activities & 368323.350 & 1 & 368323.350 & 15961.099 & .000 \\
\hline \multirow[t]{3}{*}{ group } & Learning level & 26.133 & 2 & 13.067 & 45.975 & .000 \\
\hline & Parent participation & 50.550 & 2 & 25.275 & 483.511 & .000 \\
\hline & activities & 36504.300 & 2 & 18252.150 & 790.947 & .000 \\
\hline \multirow[t]{3}{*}{ Error } & Learning level & 16.200 & 57 & .284 & & \\
\hline & Parent participation & 2.980 & 57 & .052 & & \\
\hline & activities & 1315.350 & 57 & 23.076 & & \\
\hline \multirow[t]{3}{*}{ Total } & Learning level & 524.000 & 60 & & & \\
\hline & Parent participation & 401.878 & 60 & & & \\
\hline & activities & 406143.000 & 60 & & & \\
\hline \multirow[t]{3}{*}{ Corrected Total } & Learning level & 42.333 & 59 & & & \\
\hline & Parent participation & 53.529 & 59 & & & \\
\hline & activities & 37819.650 & 59 & & & \\
\hline \multicolumn{7}{|c|}{ a. R Squared $=.617$ (Adjusted R Squared $=.604)$} \\
\hline \multicolumn{7}{|c|}{ b. R Squared $=.944$ (Adjusted R Squared $=.942)$} \\
\hline \multicolumn{7}{|c|}{ c. R Squared $=.965$ (Adjusted R Squared $=.964)$} \\
\hline
\end{tabular}

\section{Figurative display of results}

In the following figures, the results of MANOVA and correlation analysis are summarized. The numbers on the line of chains are results of the MANOVA test, and the numbers on the full lines represent the results of the correlation test

\section{Discussion}

The present research investigated the efficacy of parent involvement in children's learning and achievement in the English language, and it is emphasized that adult guidance in foreign language learning cannot necessarily play an influential role in children's zone of proximal development (ZPD). We believe that in Vygotsky's theory, there is ambiguity over some concepts such as adult guidance characteristics, and it is not evident what parents can play more effective roles in ZPD. The theory centers on the relationship and interaction between the adult and the child. 
However, foreign language learning seems to require adults to have adequate characteristics and conditions such as language knowledge and skills, be interested in involvement, and be aware of how to involve. The first research question is how parent education on the area of involvement can influence their involvement, activities, and the degree of learning in children. Results showed that there is a significant difference between experimental groups (1 and 2) and the control group in the degree of children learning and skill training, degree of involvement in parents , and the shared activities between parents and children. Moreover, the descriptive statistics analysis indicated that experimental group 1 achieved higher mean scores for the degree of learning and skill training in students, the degree of parents' involvement, and the shared activities between parents and children as compared to the experimental 2 groups and the control group. Furthermore, the experimental two obtained higher mean scores for the three mentioned variables than the control group. The results showed that educating parents on how to involve is effective and influences their quality and quantity of involvement. Therefore, education of required skills to parents should not be ignored in the process of teaching and learning in children's field especially because social networks can be powerful and effective instruments for the relationship between parents and parent-teacher association members and provide the necessary education to parents. Many studies support the present research results, declaring that parent involvement results in more achievement in learning for students and influences their social and emotional advance and their communicative and interactive skills (Al-Mahrooqi, Denman, \& Maamari, 2016). Erol Poyraz (2017) argued that it could be regarded as a critical educational source if parent involvement is effectively and correctly used in childhood education.

Maša Đurišić*1 and Mila Bunijevac2(2017) believed that schools should continuously encourage parents to involve and cooperate with schools. Erol Poyraz (2017) emphasized that teachers should guide parents on how to involve since he argued that parents do not exactly know how to involve. However, can it be practical to guide or encourage parents to engage when they do not have the necessary skills and knowledge concerning the subject matter? It seems that most of the studies on parents' engagement and children's achievements in learning (Jafarov, 2015; LaRocque, Kleiman \& Darling, 2011; Lee \& Bowen, 2006 and Forey, Besser \& Sampson, 2016) took into consideration the parents' income, occupation, socio-economic situation, education and attitude towards involvement. However, there is no research on the effectiveness of teaching how to involve parents except for Cohen, Schünke, Vogel\& Anders (2020), who investigated the influence of Support Program Chancenreich on the degree of parent's involvement and preschool children's linguistic development. However, their research topic is so different from the current research topic. Their research findings showed that if parents are trained on involvement and interaction with children, the out-ofschool environment and home can be enriched. As a result, better results can be attained regarding the children's development and skill level. Therefore, it seems that Vygotsky's Adult Guidance should be revised, especially when it comes to learning subject matters of which the adults have no knowledge and skills or their knowledge or skill is not adequate.

The second question showed a direct and positive relationship between the degree of parent involvement and the degree of learning achievement in children. In other words, the more parent involvement, the more outstanding the students' achievement in learning foreign language skills. According to Nord (1998), parent involvement plays an essential role in students' learning and achievement. Đurišić and Bunijevac (2017) stated that schools should try to enter parents into the educational process since it will promote achievement in students and increase satisfaction in parents and teachers and improve the school climate. Hosseinpour, Yazdani\& Yarahmadi (2015) investigated the factors influential in Children's English Achievement Test scores and found parent involvement vital. They did not, however, explained the exact representations of involvement.

The third research question investigated the relationship between variables in three groups and tried to find which variable had the most influence on learning in children. Results showed that parents' teaching engagement and 
linguistic skills had the most influence on their involvement, respectively. In addition, teaching engagement to parents had the most influence on child activity, followed by the variables of parent involvement and linguistic teaching skills. Finally, the results also showed that child activity and linguistic teaching skills influenced children's learning degree. It can be concluded from the results that parent involvement can be influenced by different factors such as linguistic skills and skills related to how to involve emphasized in the present research, a pointless dealt with in other studies. Nevertheless, Bubić \& Tošić (2016) argued that parent involvement could be influenced by different factors, including the critical factor of understanding the importance of involvement in the learning process by parents. They referred to examples such as beliefs and understanding the importance of involvement in children's homework and interaction with parent-teacher association members.

Therefore, it seems that such understanding can be increased through teaching parent involvement skills, actually dealt with in the present research.

Accordingly, Colbert (1996) believed that some schools should make a special effort to help low-income families get involved because many families may have economic difficulties. In addition, some have extraverted or introverted personalities.

However, Forey, Besser \& Sampson (2016) showed that teaching engagement to parents was not effective in reading aloud. There was not a positive attitude in parents in this area. Furthermore, there was a cultural difference between the parents from Hong Kong and the western parents in getting involved. Therefore, the discourse of adult guidance seems to be very complicated and under the influence of different factors that differ from one country and culture to another.

\subsection{Research limitations and future studies}

The present research concentrated on the influence of teaching engagement and linguistic skills to parents on teaching the English language to children. Moreover, it did not deal with teaching methodology in the classrooms and its influence on learning degree in children. In addition, it was just the relationship between parents and their children that was dealt with in the present research, and the relationship between parents and parent-teacher association members and teachers is open to further research. Moreover, parents are taught through social networks in the present research. Therefore, further research can be conducted on a group of parents taught via face-to-face education, and finally, a comparison can be made between the two groups. Besides, their satisfaction with the face-toface course can be compared with that in learning through social networks.

Furthermore, the present research was conducted on 60 children between 9 to 10. Further research can be performed on children of different ages. Moreover, the research addressed foreign language teaching. So, a study can be implemented on other subjects such as teaching mathematics. In addition, independent research can be conducted to extract parents' attitudes towards involvement and the necessity of acquiring knowledge to help children.

\section{Conclusion}

Although Vygotsky's learning theory is the most essential and popular theoretical framework for studies on parentchild interaction in the learning process, some concepts are ambiguous such as adult guidance. It is not clarified what kind of parents can play more effective roles in this area, what characteristics the adults should have, or whether these characteristics should be the same in all discussions and concepts. The present research showed that in learning foreign languages, adults should have language skills, be interested in involvement in the learning process, 
and have learned how to involve. Therefore, based on the above, it can be concluded that Vygotsky's theory should be reviewed or some characteristics for adult guidance be specified to reach the goals Vygotsky targeted in the ZPD.

\section{Abbreviations}

\begin{tabular}{|ll|}
\hline Abbreviation & Full \\
\hline ZDP & Zone of proximal development \\
\hline MANOVA & Multivariate analysis of variance \\
\hline PLS & Partial Least Square \\
\hline O & Opportunities \\
\hline R & Recognition \\
\hline I & Interaction \\
\hline $\mathrm{M}$ & Mode \\
\hline
\end{tabular}

\section{Declarations}

Ethic

According to domestic law, such studies, which are performed anonymously, do not require an ethics certificate.Due to the type of test design, none of the identity information led to the identification of individuals and at all stages of learning, people were coded with random codes.

\section{Availability of data and material}

It is possible to share the data of this article at the formal request of the author for research purposes.

\section{Funding}

This research was funded by Tarbiat Modares University's fund for young professors.

\section{Acknowledgements}

In this research, Ms. Sougal Chahardangeh and Dr. Mahdieh Tuyserkani have collaborated with me

\section{References}

1. Ailincai, R., Gabillon, Z., Vernaudon, J., Paia, M., \& Alì, M. (2016). School and Family Involvement in Educational Practices in French Polynesia. In The IAFOR International Conference on Education-Hawaii 2016 (pp. 199-215).

2. Al-Mahrooqi, R., Denman, C., \& Al-Maamari, F. (2016). Omani parents' involvement in their children's English education. Sage Open, 6(1), 2158244016629190. 
3. Brannon, D., \& Dauksas, L. (2012). Studying the Effect Dialogic Reading Has on Family Members' Verbal Interactions during Shared Reading. Srate Journal, 21(2), 9-20.

4. Bubić, A., \& Tošić, A. (2016). The relevance of parents' beliefs for their involvement in children's school life. Educational Studies, 42(5), 519-533.

5. Cohen, F., Schünke, J., Vogel, E., \& Anders, Y. (2020). Longitudinal effects of the family support program Chancenreich on parental involvement and the language skills of preschool children. Frontiers in Psychology, 11.

6. Colbert, R. D. (1996). The counselor's role in advancing school and family partnerships. The School Counselor, 44(2), 100-104.

7. Đurišić, M., \& Bunijevac, M. (2017). Parental involvement as a important factor for successful education. Center for Educational Policy Studies Journal, 7(3), 137-153.

8. Epstein, J. L. (2010). School/family/community partnerships: Caring for the children we share. Phi delta kappan, 92(3), 81-96.

9. Erdener, M. A., \& Knoeppel, R. C. (2018). Parents' Perceptions of Their Involvement in Schooling. International Journal of Research in Education and Science, 4(1), 1-13.

10. Fishel, M., \& Ramirez, L. (2005). Evidence-based parent involvement interventions with school-aged children. School psychology quarterly, 20(4), 371.

11. Forey, G., Besser, S., \& Sampson, N. (2016). Parental involvement in foreign language learning: The case of Hong Kong. Journal of Early Childhood Literacy, 16(3), 383-413.

12. Goodall, J. (2013). Parental engagement to support children's learning: a six point model. School Leadership \& Management, 33(2), 133-150.

13. Henderson, A. T., \& Mapp, K. L. (2002). A New Wave of Evidence: The Impact of School, Family, and Community Connections on Student Achievement. Annual Synthesis, 2002

14. Hoover-Dempsey, K. V., \& Jones, K. P. (1997). Parental Role Construction and Parental Involvement in Children's Education.

15. Hosseinpour, V., Yazdani, S., \& Yarahmadi, M. (2015). The relationship between parents' involvement, attitude, educational background and level of income and their children's English achievement test scores. Journal of Language Teaching and Research, 6(6), 1370-1378.

16. Jafarov, J. (2015). Factors affecting parental involvement in education: The analysis of literature. Khazar Journal of Humanities and social Sciences, 18(4), 35-44.Available at: 10:5782/2223-2621.2015.18.4.35

17. Kavanagh, L., \& Hickey, T. (2013). An exploration of parents' experiences of involvement in immersion schooling: Identifying barriers to successful involvement. Language learning and teaching: Irish research perspectives, 6586.

18. Kucirkova, N., Sheehy, K., \& Messer, D. (2015). A Vygotskian perspective on parent-child talk during iPad story sharing. Journal of Research in Reading, 38(4), 428-441.

19. LaRocque, M., Kleiman, I., \& Darling, S. M. (2011). Parental involvement: The missing link in school achievement. Preventing school failure, 55(3), 115-122.

20. Lawton, R. (2017). Parents' and Teachers' Perceptions of a Parental Involvement Component in Afterschool Tutoring.

21. Lee, J. S., \& Bowen, N. K. (2006). Parent involvement, cultural capital, and the achievement gap among elementary school children. American educational research journal, 43(2), 193-218. 
22. Ma, X. (2017). Parental involvement in children's foreign language learning: improving 6-12 year-old pupils' English through parent-school interaction: a case study in China (Master's thesis, Itä-Suomen yliopisto).

23. Mac Naughton, G. (2005). Doing Foucault in early childhood studies: Applying post-structural ideas. Routledge.

24. Michigan Department of Education. (2001). What research says about parent involvement in children's education in relation to academic achievement. Recuperado en Julio de 2015, del sitio Web del gobierno de Michigan: https://www.michigan.gov/documents/Final_Par ent_Involvement_Fact_Sheet_14732_7.pdf

25. Nord, C. W., Brimhall, D., \& West, J. (1998). Father involvement in schools. Champaign, IL: ERIC Clearinghouse on Elementary and Early Childhood Education, University of Illinois.

26. Nutbrown, C., Hannon, P., \& Morgan, A. (2005). Early literacy work with families: Policy, practice and research. Sage.

27. Poyraz, E. (2017). The effects of parental involvement in English language learning of secondary school students. ELT Research Journal, 6(3), 250-275.

28. Prior, J., \& Gerard, M. R. (2007). Family involvement in early childhood education: Research into practice. New York: Thomson.

29. Redding, S. (1992). Family values, the curriculum of the home, and educational productivity. School Community Journal, 2(1), 62-69.

30. Rieber, R. W., \& Robinson, D. K. (2004). Development of Thinking and Formation of Concepts in the Adolescent. In The Essential Vygotsky (pp. 415-470). Springer, Boston, MA.

31. Sargsyan, M., \& Kurghinyan, A. (2016). The use of English language outside the classroom. Journal of Language and Cultural Education, 4(1), 29-47.

32. Shim, J. M. (2013). Involving the parents of English language learners in a rural area: Focus on the dynamics of teacher-parent interactions. The Rural Educator, 34(3).

33. Tekin, A. K. (2008). AN INVESTIGATION OF TURKISH PARENTS'BELIEFS AND PERCEPTIONS FOR INVOLVEMENT IN THEIR YOUNG CHILDREN'S EDUCATION.

34. Vygotsky, L. S. (1978). Socio-cultural theory. Mind in society, 6, 52-58.

35. Waterman, R. (2009). Communication is more than language: Adult ESL classes foster parent-school collaboration. Bilingual Research Journal, 31(1-2), 227-250.

36. Xiao, L., Bechara, A., Palmer, P. H., Trinidad, D. R., Wei, Y., Jia, Y., \& Johnson, C. A. (2011). Parent-child engagement in decision-making and the development of adolescent affective decision capacity and bingedrinking. Personality and individual differences, 51(3), 285-292.

37. Yusup, N. B., \& Mansora, A. A. (2016). The influence of parents support and its relationship with students achievement in English education. In The Proceedings of International Conference on Education and Regional Development 2016 (ICERD 2016) (pp. 657-662).

\section{Figures}


Learning in

the home

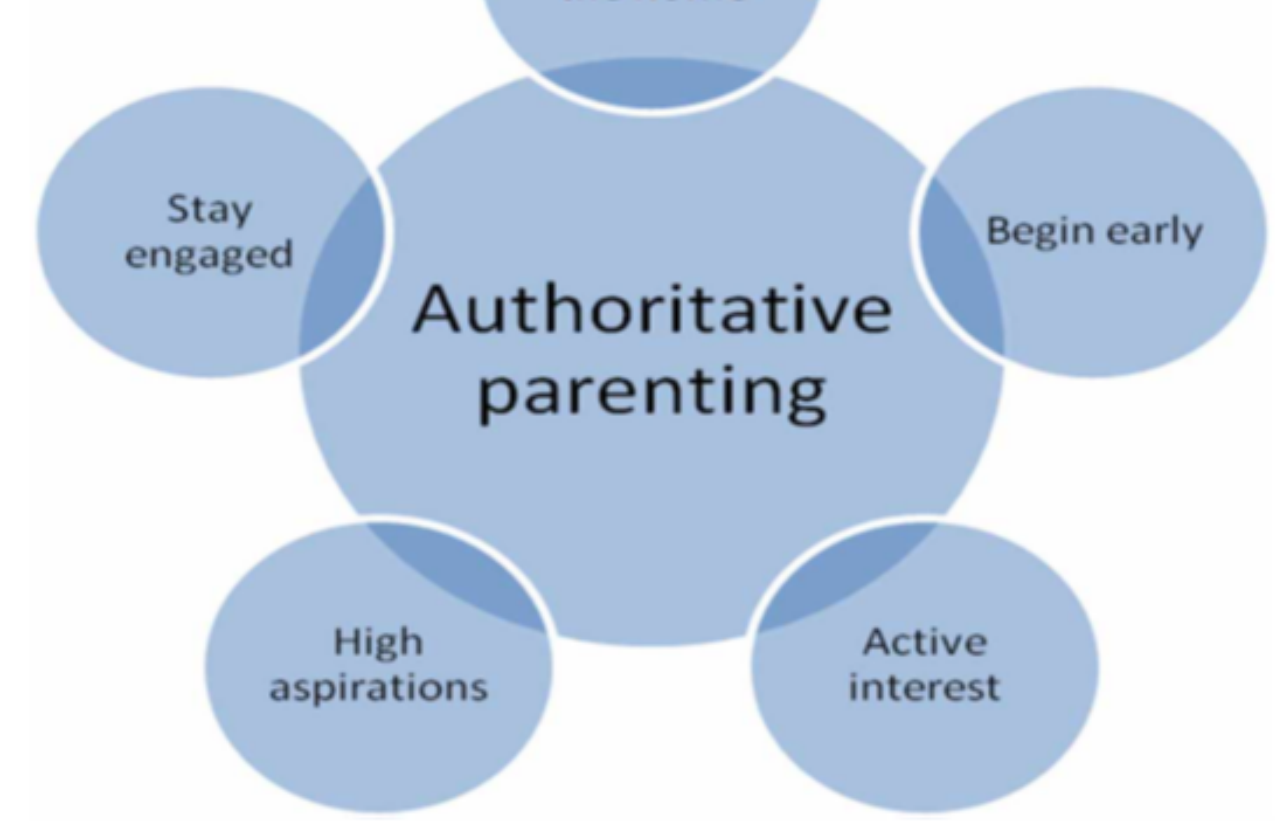

Figure 1

authoritative parenting

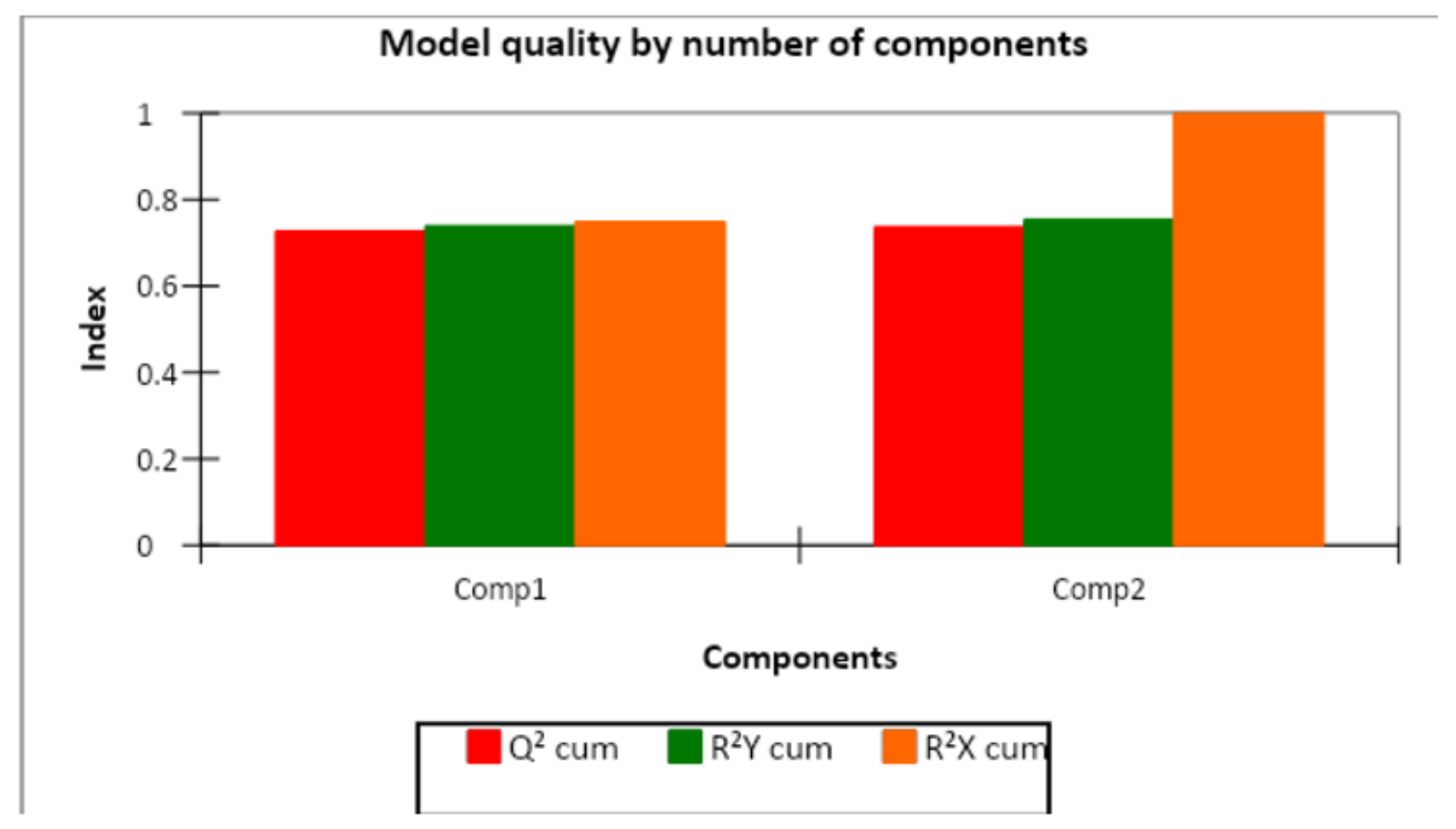


Figure 2

Model efficacy investigation with different components

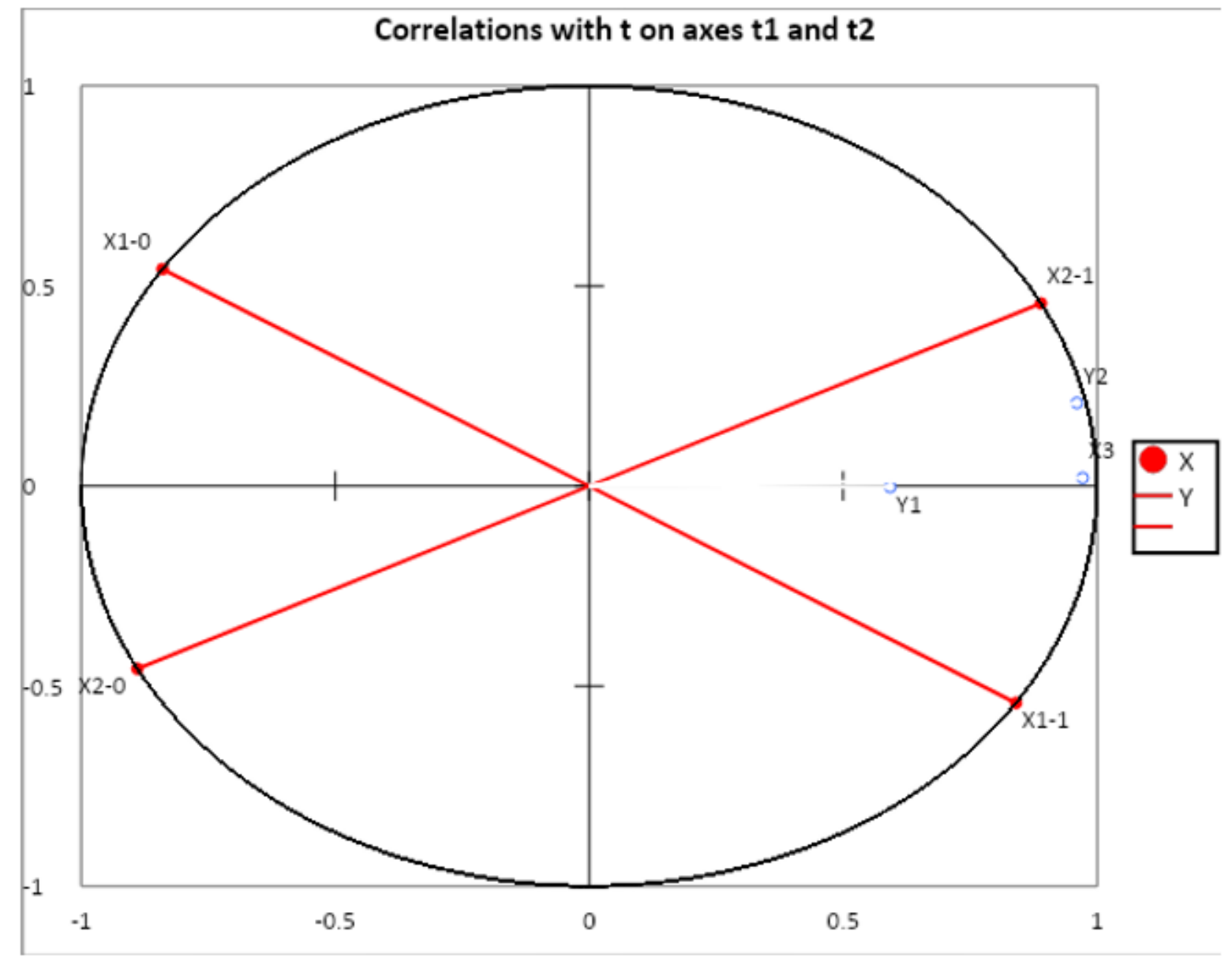

Figure 3

Correlation circle of the dependent variables $(Y 1, Y 2$, and $X 3)$, independent variables $(X 1$ and $X 2)$, and groups (1, 2, and 3) with the first two PLS components $(t 1, t 2)$. 


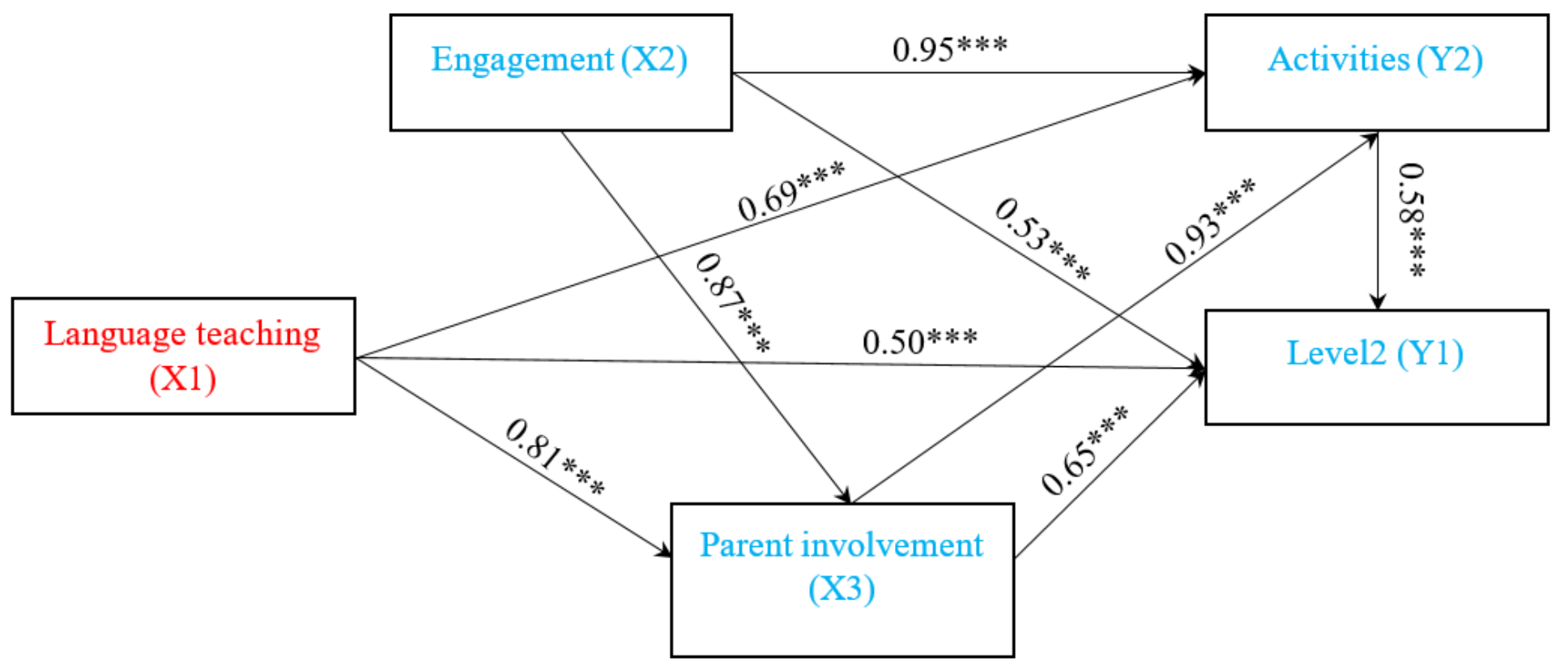

Figure 4

Standardized regression coefficients above arrows show direct effects from linear models $(n=60, * \star * P<0.001)$

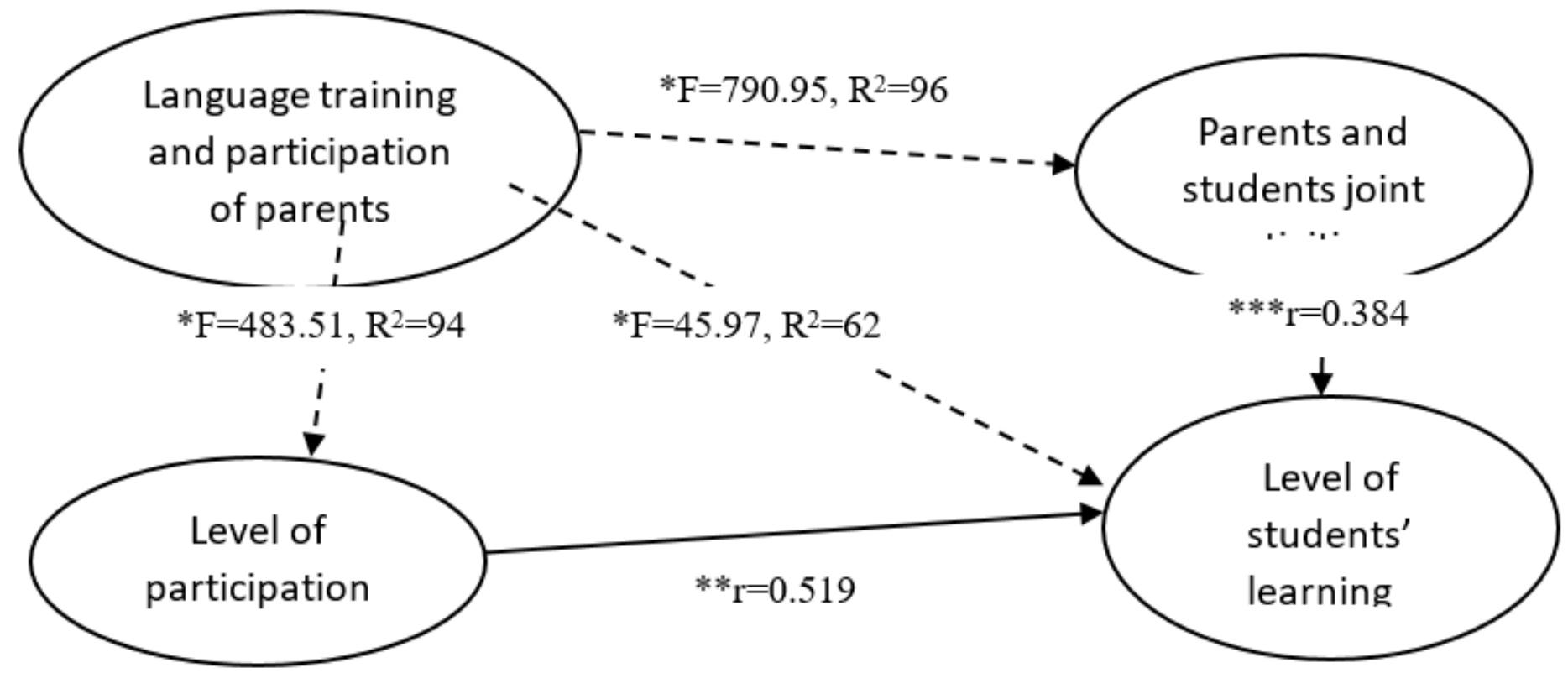

Figure 5

conceptual model for the first group 


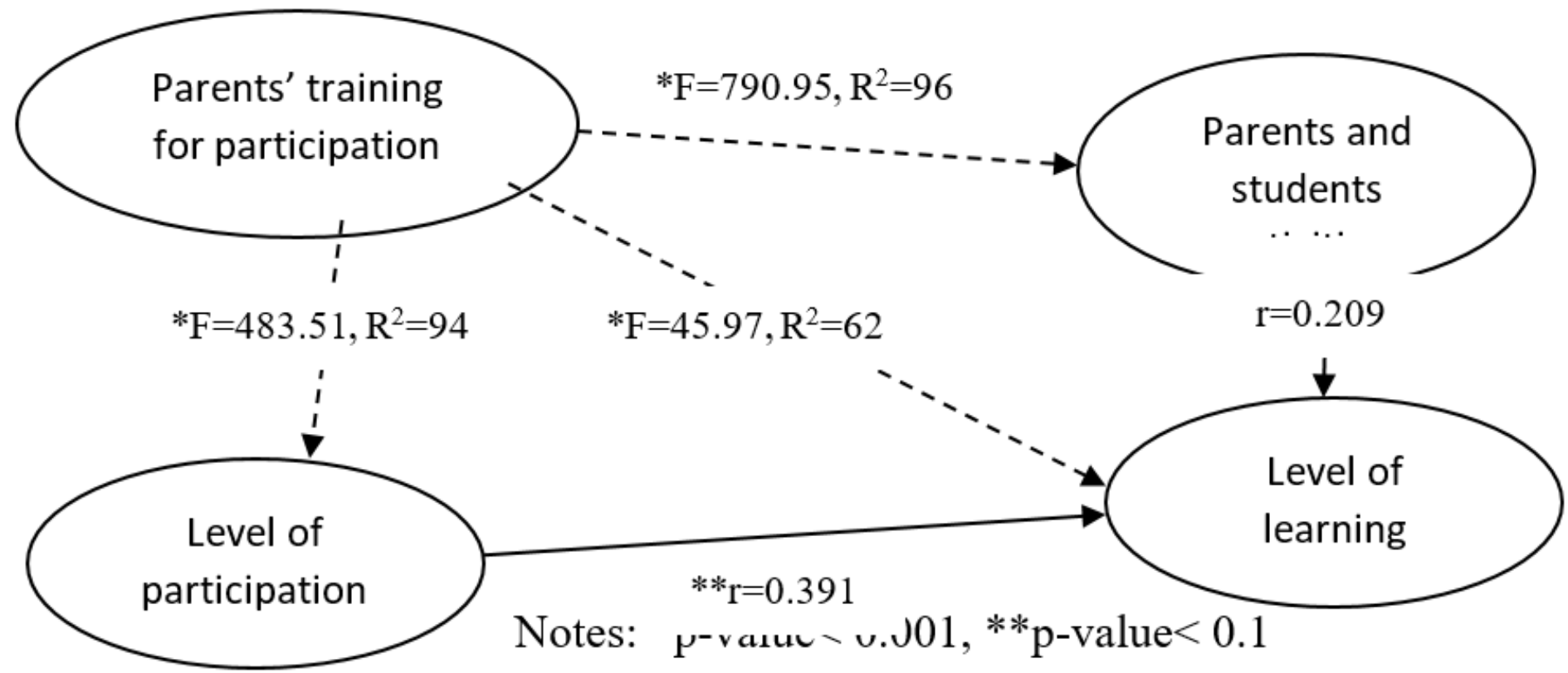

Figure 6

conceptual model for the second group

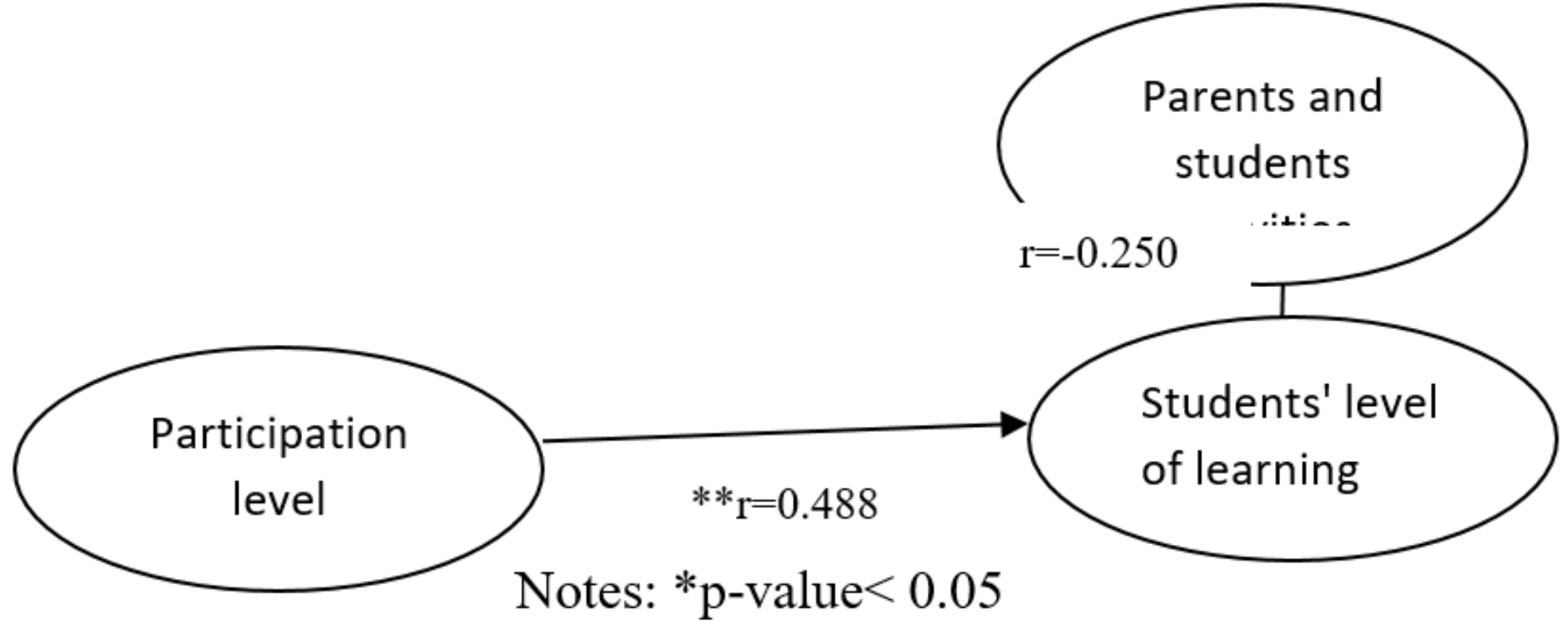

Figure 7

conceptual model for control group 